\title{
DETERMINASI KONSENTRASI SAKSITOKSIN PADA KERANG HIJAU DARI PASAR DI SEKITAR TELUK JAKARTA SERTA BAGAN DI TELUK LAMPUNG DAN TELUK PANIMBANG
}

\section{Determination of Saxitoxin Concentration of Green Mussel Collected from Markets Around Jakarta, and from Original Sources at Lampung Bay and Panimbang Bays}

\author{
Haryoto Kusnoputranto ${ }^{1}$, Setyo S. Moersidik ${ }^{2}$, Murdahayu Makmur ${ }^{3 *}$, dan Dwiyitno ${ }^{4}$ \\ ${ }^{1}$ Departemen Kesehatan Lingkungan FKM dan Program Studi IImu Lingkungan PPS Universitas Indonesia. \\ Gedung C Lt. 2 Kampus FKMUI Depok \\ ${ }^{2}$ Departemen Teknik Lingkungan FT dan Program Studi IImu Lingkungan PPS Universitas Indonesia \\ Gedung GK Lantai 1, Fakultas Teknik Kampus UI Depok 16424 \\ ${ }^{3}$ Badan Tenaga Nuklir Nasional, Kawasan PUSPIPTEK Gedung 20 \& 65, Serpong Tangerang 15314 \\ ${ }^{4}$ Balai Besar Penelitian dan Pengembangan Pengolahan Produk dan Bioteknologi Kelautan dan Perikanan, KKP. \\ JI. K.S. Tubun Petamburan VI, Jakarta Pusat 10260 \\ * Korespondensi Penulis: mdhayu@batan.co.id \\ Diterima: 6 Juli 2012, Disetujui: 11 November 2013
}

\begin{abstract}
ABSTRAK
Telah dilakukan determinasi konsentrasi saksitoksin (STX) dari 9 sampel kerang hijau yang dikumpulkan dari beberapa pasar di Jakarta (Cilincing, Dadap dan Muara Karang), Teluk Lampung dan Teluk Panimbang. Penentuan konsentrasi saksitoksin dilakukan dengan menggunakan detektor fluoresensi HPLC. Dari hasil pengukuran didapatkan bahwa konsentrasi saksitoksin pada sampel kerang Pasar Cilincing berkisar antara 6,9165-17,3387 $\mu \mathrm{g}$ STXeq. per $100 \mathrm{~g}$ daging kerang, Pasar Dadap berkisar antara 7,7466-11,7575 $\mu$ g STXeq. per 100 g, Pasar Muara Karang sebesar 4,9280 $\mu \mathrm{g}$ STXeq. per $100 \mathrm{~g}$, Teluk Lampung sekitar 7,2946 $\mu \mathrm{g}$ STXeq. per $100 \mathrm{~g}$ dan Teluk Panimbang sekitar 6,3876 $\mu \mathrm{g}$ STXeq. per $100 \mathrm{~g}$. Mengacu SNI 3460.1:2009 tentang Spesifikasi Daging Kerang Beku, konsentrasi saksitoksin dalam kerang hijau di daerah tersebut masih di bawah ambang yang diperbolehkan yaitu $80 \mu \mathrm{g}$ STXeq. per $100 \mathrm{~g}$ daging kerang.
\end{abstract}

KATA KUNCl: $\quad$ saksitoksin, kerang hijau, HPLC

\begin{abstract}
S
Determination of saxitoxin (STX) concentration of 9 samples of green mussel collected from several markets in Jakarta (Cilincing, Dadap and Muara Karang), and from original sources at Lampung Bay and Panimbang Bay has been carried out using HPLC fluorescence detector. Results showed that the saxitoxin concentration of shellfish samples from Cilincing Market ranged from 6.9165-17.3387 $\mu \mathrm{g}$ STXeq. per $100 \mathrm{~g}$, Dadap Market ranged from 7.7466-11.7575 $\mu \mathrm{g}$ STXeq. per 100 g. Muara Karang Market approximately 4.9280 mg STXeq. per 100 g, Lampung Bay approximately $7.2946 \mu \mathrm{g}$ STXeq. per $100 \mathrm{~g}$, and Panimbang Bay approximately 6.3876 $\mu \mathrm{g}$ STXeq. per $100 \mathrm{~g}$. Referred to SNI 3460.1:2009 concerning with Frozen Shellfish Meat Specifications, the saxitoxin level in green mussels in these area is still below the threshold limit of $80 \mu \mathrm{g}$ STXeq. per $100 \mathrm{~g}$.
\end{abstract}

KEYWORDS: $\quad$ saxitoxin, green mussel, HPLC

\section{PENDAHULUAN}

Kejadian ledakan alga (algal bloom), yang biasa dikenal dengan red tide meningkat sangat pesat akhirakhir ini hampir di seluruh dunia, termasuk di Indonesia yang menyebabkan rusaknya tatanan lingkungan perairan laut dan juga mengancam kesehatan manusia melalui rantai makanan. Dari 5000 jenis alga yang diketahui, 300 diantaranya berpotensi untuk tumbuh dengan sangat pesat dan $40 \%$ diantaranya mempunyai kemampuan untuk menghasilkan toksin yang berisiko terhadap manusia melalui ikan, kekerangan atau jalur makanan lainnya (Hallegraeff, 1993). 
Pada umumnya, toksin yang dihasilkan oleh alga terbagi dalam lima grup berdasarkan gejala yang dihasilkan, yaitu Paralytic Shellfish Poisoning (PSP), Diarhetic Shellfish Poisoning (DSP), Amnesic Shellfish Poisoning (ASP), Ciguatera Shellfish Poisoning (CSP) dan Neurotoxic Shellfish Poisoning (NSP) (FAO), 2004). Toksin PSP, yang dikenal dengan nama saksitoksin (STX) dihasilkan oleh alga toksik seperti Alexandrium tamarense, Pyrodinium bahamense var Compressum (PbC), Gymnodinium catenatum dan beberapa dinoflagelata lain (Dam et al., 2009).

Alga toksik yang menghasilkan saksitoksin di Asia Pasifik didominasi oleh Alexandrium spp, dan di Australia didominasi oleh Gymnodium catenatum. Pyrodinium bahemense dominan di Asia Tenggara dan Pasifik Selatan termasuk Philipina, Malaysia dan Brunei. Di Jepang, Alexandrium catenella ditemukan pertama kali di Owase Bay, dan secara luas terdistribusi di sebagian besar bagian utara sampai selatan Jepang (Ashley et al., 2005). Saksitoksin banyak ditemukan di bivalva dan gastropoda (yang memangsa bivalva) dan melalui rantai makanan akan sampai ke manusia yang mengkonsumsi produk perikanan laut yang telah terkontaminasi oleh saksitoksin.

Saksitoksin dengan 20 derivatnya merupakan jenis toksin yang paling aktif dalam menghambat (blocking) saluran-saluran dari susunan saraf dan membran, menyebabkan mulai dari sensasi tebal di sekitar mulut sampai terjadi paralisis atau kelumpuhan pada otot jantung yang memicu kematian (EFSA, 2009). Saksitoksin berikatan dengan saluran sodium pada sel syaraf, kemudian menghambat jalur ion sodium. Satu molekul saksitoksin tunggal cukup untuk menghambat satu saluran ion sodium dan lebih beracun dibandingkan dengan gas syaraf sarin sehingga digolongkan ke dalam senjata biologi (Cbwinfo, 2009).

Saksitoksin berupa cairan tidak berwarna dengan bau menyengat (seperti asam cuka), dan mempunyai berat jenis $1,0 \mathrm{~g} / \mathrm{ml}$. Saksitoksin bersifat racun dan menyebabkan iritasi jika kontak dengan kulit, mata, pernafasan dan mulut. Senyawa ini mempunyai nilai $\mathrm{LD}_{50}$ sebesar $263 \mathrm{~g} / \mathrm{kg}$ bobot badan (oral mencit). Saksitoksin mempunyai sifat fisik larut dalam air dan metil alkohol, sedikit larut dalam etil alkohol dan asam asetat tetapi tidak larut dalam pelarut organik (nonpolar). Senyawa ini mudah terhidrolisis dalam larutan basa dan toksinnya tidak aktif setelah dididihkan selama 3 sampai dengan 4 jam pada $\mathrm{pH}$ 3. Saksitoksin tidak dapat dihilangkan dari makanan laut baik melalui proses pemanasan maupun hidrolisis (Cbwinfo, 2009).
Sampai pertengahan 1994, sebanyak 3.164 kasus keracunan toksin alga dilaporkan dan 148 orang meninggal dari kawasan Asia Pasifik (Corrales \& Maclean, 2000). Sedangkan Ashley (2005) melaporkan bahwa pada tahun 1989, di Dongshan China, karena mengkonsumsi kerang toksik Venerupis philippinarum, menyebabkan satu orang meninggal dan 136 lainnya sakit serius. Pada tahun 1991, dua kejadian fatal dilaporkan karena mengkonsumsi Perna viridis yang mengandung toksin dari perikanan laut di Daya Bay, Provinsi Gandong. Dari 24 spesies kerang yang ditemukan, Chlamys nobilis dan $P$. viridis yang paling toksik (Ashley et al., 2005).

Perpindahan dan penyebaran alga toksik di perairan biasanya melalui arus laut dan air ballast kapal. Penyebaran alga toksik di Indonesia bagian timur diperkirakan karena arus laut, sedangkan di Teluk Jakarta dan Teluk Lampung yang mempunyai aktifitas pelayaran yang tinggi, diasumsikan berasal dari dari air ballast kapal yang masuk ke pelabuhan.

Beberapa spesies alga toksik dijumpai di perairan Teluk Jakarta, seperti Protoperidinium spp, Gymnodinium spp, dan Alexandrium spp, walaupun masih dalam jumlah sedikit (Sutomo, 1993). Kematian puluhan ribu ekor ikan, udang, kepiting, kerang, dan remis yang terjadi di perairan Ancol Jakarta, pada bulan Mei dan November tahun 2004 diduga disebabkan karena ledakan alga sehingga ikan kekurangan oksigen atau tersumbatnya insang karena tingginya kelimpahan fitoplankton. Kelimpahan

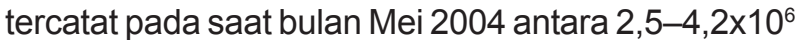
sel/l dengan 12 spesies, terdiri atas 4 spesies diatom and 8 spesies dinoflagelata. Pada November 2004, kelimpahan dinoflagelata sekitar $2,8 \times 10^{6} \mathrm{sel} / \mathrm{l}$, dengan dominasi oleh Prorocentrum micans $\left(2,3 \times 10^{6} \mathrm{sel} / \mathrm{l}\right)$ (Thoha et al., 2007). Sedangkan di Teluk Lampung pada tahun 1999 ditemukan alga $\mathrm{PbC}$ sebesar $8,9 \times 10^{4}$ sel/L dan meningkat lebih dari 2 kali lipatnya menjadi

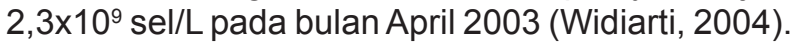

Kondisi perairan yang subur di teluk Jakarta perlu diwaspadai terhadap kemungkinan terjadinya blooming alga toksik terutama dinoflagelata. Saksitoksin dari alga dapat berpindah ke manusia melalui biomarker spesifik di perairan tersebut, seperti kerang hijau yang banyak di budidayakan di perairan Teluk Jakarta. Budidaya kerang hijau di Cilincing pada tahun 2006 menghasilkan 200.000 ton kerang hijau dari 1.396 bagan (BPS, 2011).

Penelitian mengenai kandungan saksitoksin pada kekerangan masih jarang dilakukan, walaupun kejadian keracunan kerang beberapa kali terjadi di Indonesia. Lusiastuti (2003) melaporkan bahwa kandungan saksitoksin pada sampel kerang yang diambil dari pesisir timur Sumatera dan Teluk Jakarta 
berkisar antara 24-70 $\mu \mathrm{g}$ STXeq. per $100 \mathrm{~g}$. Penentuan konsentrasi saksitoksin dilakukan dengan Elisa Reader(Lusiastuti, 2003). Sementara Mulyasari (2003) menyatakan bahwa konsentrasi saksitoksin dari sampel kerang hijau dan kerang dara dari perairan Tanjung Pasir Tangerang dan Cilincing pada tahun 2001 berkisar antara 2,1-2,3 $\mu \mathrm{g}$ STXeq. per $100 \mathrm{~g}$. Penentuan kandungan saksitoksin dilakukan dengan menggunakan High Performance Liquid Chromatography Fluorescence Detection (HPLC-FD) dan Mouse Bio Assay (MBA) (Mulyasari, et al., 2003).

Riset ini bertujuan untuk meneliti konsentrasi saksitoksin pada kerang hijau yang di jual di pasar dan di habitat tempat hidupnya. Penentuan konsentrasi saksitoksin pada kerang hijau merupakan critical point dalam melindungi kesehatan masyarakat dari kerentanan jejaring makanan. Hasil penelitian ini dapat digunakan sebagai dasar informasi untuk kajian risiko toksin alga terutama saksitoksin yang dapat digunakan dalam manajemen dan komunikasi risiko.

\section{BAHAN DAN METODE}

\section{Keterbatasan Penelitian}

Dalam penelitian ini tidak dilakukan validasi recovery, karena keterbatasan standar yang dimiliki, sehingga hilangnya saksitoksin selama proses preparasi dan ekstraksi tidak diketahui. Sebagai contoh, untuk mendapatkan konsentrasi $0,8 \mathrm{ug} / \mathrm{g}$, dibutuhkan $4 \mu \mathrm{g}$ standar saksitoksin untuk setiap $5 \mathrm{~g}$ sampel, apalagi bila dilakukan duplikasi atau triplikasi karena standar tidak tersedia komersial dan sulit untuk mendapatkannya. Namun, diharapkan, hasil penelitian ini dapat memberikan kisaran konsentrasi saksitoksin di dalam kerang hijau yang ada di beberapa daerah.

\section{Bahan dan Peralatan}

Sistem HPLC yang dipakai menggunakan pompa jenis Water 1523 Binary HPLC pump, dilengkapi dengan pengatur suhu (water temperature control module). Untuk monitoring, digunakan detektor fluoresensi jenis water 2475 multi I fluorescence detector dari Milford dengan panjang gelombang eksitasi $340 \mathrm{~nm}$ dan panjang gelombang emisi 395 $\mathrm{nm}$. Software Empower2 Quick Stars Interface digunakan untuk analisis data dan report. Kolom yang digunakan adalah Agilent zorbax Rx-C18 (4,6 mm id x $250 \mathrm{~mm}, 5 \mu \mathrm{m}$ ) dari Agilent Tech, USA.

Produk oksidasi STX dielusi menggunakan gradien linear dari 2 fasa gerak, yaitu: (a), amonium format $0,1 \mathrm{M}$ dan (b), amonium format $0,1 \mathrm{M}$ dalam $5 \%$ asetonitril yang diset pada $\mathrm{pH} 6$ dengan menambahkan asam asetat 0,1 $\mathrm{M}$.
Peralatan lain yang digunakan adalah penangas, vortex mixer, kertas $\mathrm{pH}$, sentrifus (Beckman model J2-21), tabung sentrifus polipropilen $50 \mathrm{ml}$, tabung reaksi berskala 5 dan $15 \mathrm{ml}$, dan cartridge C18-Agilent C18-ODS-Cartrigde (500 mg/3 ml volume) dari Agilent Tech, USA.

Standar saksitoksin didapatkan dari hibah kerjasama BATAN pada kegiatan RCA-RAS/7/017. Rentang konsentrasi yang digunakan adalah 1-5 ppb yang diencerkan dari larutan induk 20 ppb. Reagen lain yang digunakan adalah air, asetonitril, dan metanol (JT BakerAnalyzed @HPLC Solvent), amonium format (Sigma Aldrich), asam asetat glasial, sodium hidroksida, dan peroksida.

\section{Metode}

\section{Pengumpulan Sampel dan Preparasi}

Kerang hijau dibeli di pasar Cilincing pada 2 Juni 2010 (kode sampel: Cil 1), 25 Januari 2011 (Cil 2) dan 25 Maret 2011(Cil 3). Sampel Dadap diambil pada tanggal 2 Juni 2010 (kode sampel: Ddp 1), 25 Januari 2011 (Ddp 2) dan 18 Maret 2011 (Ddp 3), sedangkan sampel Muara Karang (Mkr) diambil pada 19 Maret 2011. Sampel Teluk Panimbang di Labuan Banten diambil dari bagan kerang milik Unit Depurasi Kekerangan yang terletak di laut dekat unit depurasi pada 14 Maret 2011 (kode sampel: Pnb), dimana di lokasi yang sama juga terdapat bagan bagan kerang nelayan kerang hijau. Sedangkan sampel Teluk Lampung diambil dari tiang pancang dermaga kapal di Pelabuhan Panjang pada tanggal 24 Maret 2011 (kode sampel Lmp). Sampel kerang hijau dengan kode Cil 1 dan Ddp 1, yang diambil pada bulan Juni 2010 mewakili sampel pada musim kemarau sedangkan sampel lainnya yang diambil pada Januari sampai Maret 2011 mewakili musin hujan.

Sampel dikumpulkan dan dipilih yang mempunyai ukuran hampir sama, yaitu dengan panjang cangkang $\pm 7 \mathrm{~cm}$ sebanyak 20-30 ekor. Sampel dibawa ke laboratorium untuk dipreparasi dan diekstraksi. Sampel kemudian disimpan pada suhu $-20^{\circ} \mathrm{C}$ sebelum diukur kadar STXnya. Prosedur preparasi, ekstraksi, pemurnian, oksidasi dan pengukuran dengan HPLC mengikuti prosedur AOAC Official Method 2005.06 (AOAC, 2006).

\section{Ekstraksi Sampel}

Sampel kerang dicuci dengan air bersih, dibuka dan diambil semua bagian lunaknya sebanyak $100 \mathrm{~g}$. Sampel dihomogenkan dengan blender dan kemudian ditimbang sebanyak $5 \pm 0,1 \mathrm{~g}$ dalam tabung reaksi poli propilen $50 \mathrm{ml}$, dan ditambahkan $3 \mathrm{ml}$ asam asetat $1 \%$. Sampel kemudian dihomogenkan dengan vortex 
mixer kemudian ditempatkan pada water bath $100^{\circ} \mathrm{C}$ selama 5 menit. Permukaan larutan sampel dijaga tetap di bawah permukaan air water bath dan temperatur dijaga tidak turun lebih dari 30 detik. Sampel kemudian dikeluarkan dari water bath, dihomogenkan lagi dengan vortex mixer dan ditempatkan dalam refrigerator atau dalam potongan es selama 5 menit. Sampel dihomogenkan dengan vortex mixer dan dilanjutkan dengan sentrifus selama 10 menit pada $4.500 \mathrm{rpm}$ dan supernatant diambil. Residu yang tersisa ditambahkan $3 \mathrm{ml}$ asam asetat $1 \%$ dan dihomogenkan lagi dengan vortex mixer dan sentrifus. Kedua supernatan digabung dan ditepatkan volumenya menjadi $10 \mathrm{ml}$ dengan air (AOAC, 2006).

\section{SPE C18 Cleanup}

Cartridge SPE C18 (3 ml, $500 \mathrm{mg}$ sorbent) dikondisikan dengan $6 \mathrm{ml}$ metanol, diikuti dengan 6 $\mathrm{ml}$ air. Kemudian $1 \mathrm{ml}$ (setara dengan 0,5 g) ekstrak kerang ditambahkan ke dalam cartridge. Kecepatan alir dijaga kira-kira 2-3 ml per menit. Efluen ditampung dan ditambahkan $2 \mathrm{ml}$ air ke dalam cartridge dan efluennya digabung. $\mathrm{pH}$ dijadikan 6,5 dengan penambahan $\mathrm{NaOH} 1 \%$. Volume sampel ditepatkan $4 \mathrm{ml}$ dengan air (AOAC, 2006).

\section{Oksidasi Peroksida}

Sebanyak $25 \mu \mathrm{H}_{2} \mathrm{O}_{2} 10 \%$ dan $250 \mu \mathrm{l} \mathrm{NaOH} 1 \mathrm{M}$ dicampur dalam tabung sentrifus $1,5 \mathrm{ml}$, kemudian dihomogenkan dengan vortex mixer. Sebanyak 100 $\mu \mathrm{l}$ standar atau sampel (setelah C18 cleanup) ditambahkan dan dihomogenkan dengan vortex mixer. Sampel dibiarkan selama 2 menit pada suhu kamar, kemudian ditambahkan $20 \mu \mathrm{l}$ asam asetat pekat, dihomogenkan kembali dengan vortex mixer dan dibiarkan lebih kurang 30 menit untuk kestabilan larutan sebelum di injek ke HPLC.

\section{Pengukuran dengan HPLC}

Gradien yang digunakan untuk mengelusi saksitoksin adalah sebagai berikut: 0-5\% B selama 5 menit, 5-70\% B selama 4 menit, kembali ke 0\% B selama 2 menit dan $0 \%$ B selama 7 menit sebelum injek berikutnya. Kecepatan alir yang digunakan adalah $1 \mathrm{ml} /$ menit.

\section{Perhitungan}

Perhitungan konsentrasi saksitoksin dalam $\mu \mathrm{g} / \mathrm{kg}$ (edible part).

Konsentrasi STX $(\mu \mathrm{gg} / \mathrm{kg})=\frac{A_{x} C_{s} V_{x} D}{A_{s} M}$

$\mathrm{A}_{\mathrm{x}}=$ peak area toksin yang dianalisis
$A_{s}=$ peak area standar

$\mathrm{C}_{\mathrm{s}}=$ konsentrasi standar $(\mu \mathrm{g} / \mathrm{l})$

$\mathrm{V}_{\mathrm{x}}=$ volume final dari ekstrak yang dianalisis $(\mathrm{ml})$

$D$ = faktor pengenceran

$\mathrm{M}=$ jumlah yang dilewatkan melalui $\mathrm{C} 18$ cleanup (g)

\section{HASIL DAN BAHASAN}

\section{Pemilihan Daerah Sampling}

Cilincing dan Dadap dipilih sebagai tempat pengambilan sampel karena kedua daerah tersebut merupakan lokasi budidaya kerang hijau yang terbesar di Jakarta, sedangkan Pasar Muara Karang dipilih karena merupakan TPI yang menjual hasil laut termasuk kerang hijau dari daerah sekitar, walaupun sumber terbesar kerang hijau berasal dari Dadap dan Cilincing. Sampel Pasar Muara Karang yang dicuplik ini ternyata berasal dari Dadap, yang dipanen sehari sebelumnya.

Sampel kerang hijau yang diambil dari Teluk Panimbang-Banten digunakan sebagai pembanding, karena Teluk Panimbang merupakan perairan yang relatif bersih dan tidak banyak mengandung limbah (Panggabean, 2009), apalagi Pemprov Banten telah menetapkan daerah Panimbang sebagai daerah untuk budidaya kerang hijau dan telah membangun unit sanitasi kekerangan di daerah tersebut. Selain hal tersebut, Panimbang merupakan salah satu daerah tujuan relokasi budidaya kerang hijau dari Teluk Jakarta yang digulirkan oleh PemProv DKI Jakarta yang diajukan dalam kajian eksistensi budidaya kerang hijau di Teluk Jakarta pada Tahun 2006 (Dinas Nakala, 2006).

Pada waktu pengambilan sampel Panimbang, tidak ditemukan kerang hijau yang dijual di pasar karena memang tidak sedang musim panen sehingga sampel diambil dari bagan kerang hijau milik Unit Sanitasi Kekerangan yang berada persis di laut depan unit sanitasi. Hal ini berbeda dengan pengambilan sampel di Cilincing dan Dadap yang dilakukan di pasar, karena budidaya kerang di kedua tempat tersebut mempunyai masa panen yang panjang dan hampir setiap waktu.

Sampel Teluk Lampung diambil berdasarkan hasil penelitian Widiarti (2004) tentang ditemukan alga PbC di Teluk Lampung dengan kelimpahan yang tinggi. Keberadaan Pyrodinium di perairan Teluk Lampung pertama kali diketahui pada tahun 1999, di Desa Hanura. Pada saat ditemukan, terdapat $8,9 \times 10^{4}$ sel dalam tiap liter air laut. Jumlah tersebut meningkat lebih dari 2 kali lipat menjadi $2,3 \times 10^{9}$ sel per liter air laut pada bulan April 2003. Dengan demikian, kerang hijau yang dibudidayakan di perairan Teluk Lampung 
diduga mengandung saksitoksin. Namun pada saat survei untuk pengambilan sampel, tidak ditemukan kerang hijau yang dijual di Teluk Lampung sehingga akhirnya pengambilan sampel dilakukan di dermaga kapal Pelabuhan Panjang.

\section{Penentuan Konsentrasi Saksitoksin menggunakan HPLC Detektor Fluoresensi}

Deteksi kandungan konsentrasi saksitoksin dilakukan menggunakan HPLC Detektor fluoresensi dengan cara membandingkan waktu retensi standar dengan waktu retensi sampel. Gambar 1 menunjukkan bahwa untuk spektrum standar $5 \mathrm{ppb}$, puncak saksitoksin keluar pada menit ke 2-3, demikian juga untuk sampel Teluk Lampung pada Gambar 2, puncak saksitoksin juga keluar pada menit ke 2-3. Dengan demikian, sampel teluk Lampung dipastikan mengandung saksitoksin.
Konsentrasi saksitoksin dalam sampel ditentukan dengan membandingkan peak area standar dengan peak area sampel dengan menggunakan persamaan seperti yang telah dijabarkan pada metodologi. Spektrum standar yang dijadikan sebagai pembanding adalah spektrum standar yang mempunyai konsentrasi yang berdekatan dengan sampel yang ditandai dengan jumlah peak area kedua spektrum yang hampir sama. Spektrum standar yang digunakan dalam menentukan konsentrasi saksitoksin dalam sampel adalah spektrum standar dengan konsentrasi $5 \mathrm{ppb}$, karena hampir semua sampel mempunyai jumlah peak area yang mendekati spektrum $5 \mathrm{ppb}$ atau lebih.

\section{Kandungan Saksitoksin dalam Sampel Kerang Hijau}

Hasil perhitungan menunjukkan bahwa konsentrasi saksitoksin berkisar dari 4,928 $\mu \mathrm{g}$ STXeq. per $100 \mathrm{~g}$

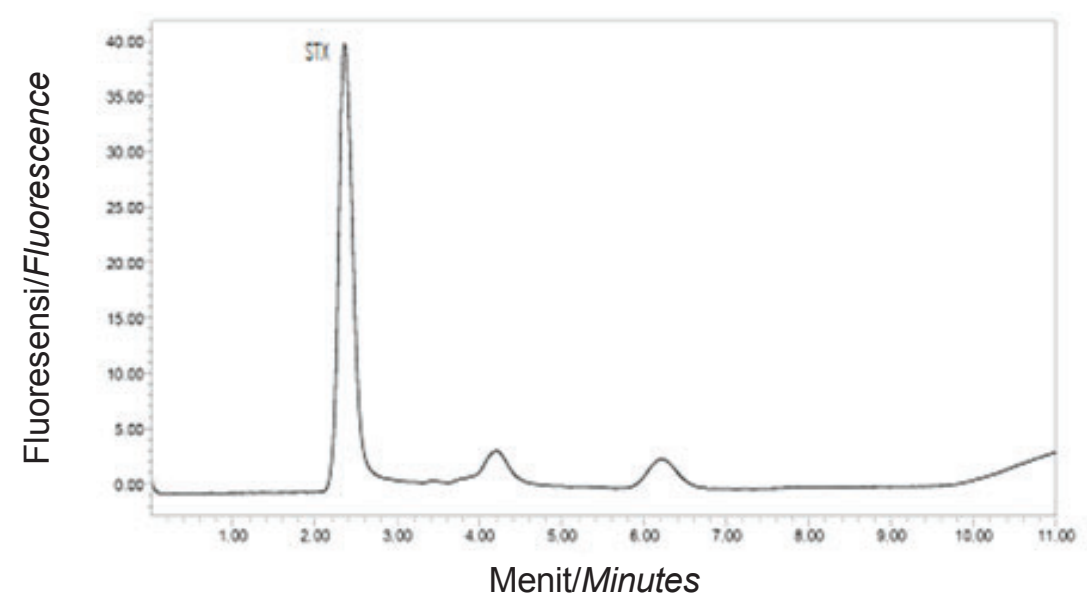

Gambar 1. Spektrum HPLC untuk standar saksitoksin $5 \mathrm{ppb}$. Figure 1. HPLC spectrum for saxitoxin standar at $5 \mathrm{ppb}$.

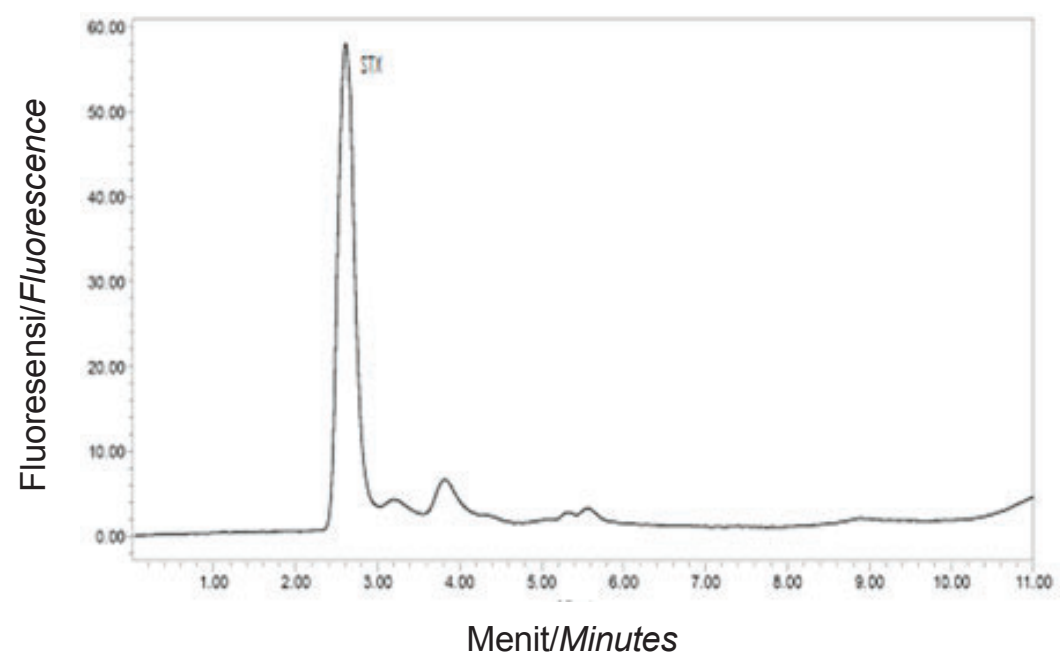

Gambar 2. Spektrum HPLC untuk Sampel Teluk Lampung. Figure 2. HPLC spectrum for saxitoxin in Lampung Bay Sample. 
daging kerang (sampel Muara Karang) sampai dengan $17,3378 \mu \mathrm{g}$ STXeq. per $100 \mathrm{~g}$ daging kerang (pada sampel Cilincing 1).

Dari data hasil analisis, ditemukan bahwa konsentrasi saksitoksin pada kerang hijau masih di bawah tingkat toleransi saksitoksin yang ditetapkan. Indonesia menetapkan konsentrasi $80 \mu \mathrm{g}$ STXeq. per $100 \mathrm{~g}$, yang diatur pada SNI 3460.1:2009 tentang daging kerang beku (BSN, 2009). Dengan terpenuhinya persyaratan mutu tersebut, maka diharapkan masyarakat yang mengkonsumsi produk kekerangan dapat terhindar dari resiko gangguan kesehatan. Sebaran data konsentrasi saksitoksin pada kerang hijau dan baku mutu sebagai pembanding dapat dilihat pada Gambar 3 berikut ini. konsumen. Seperti pada sampel kerang hijau yang diperoleh dari Cilincing pada tanggal 2 Juni 2010, mengandung STX sebesar 17,3387 $\mu$ S STXeq. per 100 $\mathrm{g}$ dan dengan menggunakan porsi sekali makan yang disepakati European Food Safety Authority (EFSA) yaitu sejumlah porsi $400 \mathrm{~g}$, maka akan didapat pajanan terhadap konsumen dengan berat badan 60 kg sebesar 1,16 $\mu \mathrm{g}$ STXeq. per kg.bb. Hal ini masih di bawah tingkat toleransi yang disepakati EFSA yaitu $5,33 \mu \mathrm{g}$ STXeq. per kg.bb yang merupakan batas pajanan yang tidak memberikan risiko terhadap konsumen yang mengkonsumsi kerang.

Konsentrasi saksitoksin di dalam daging kerang berhubungan erat dengan kelimpahan alga penghasil PSP toksin yang ada di perairan dimana kerang hijau

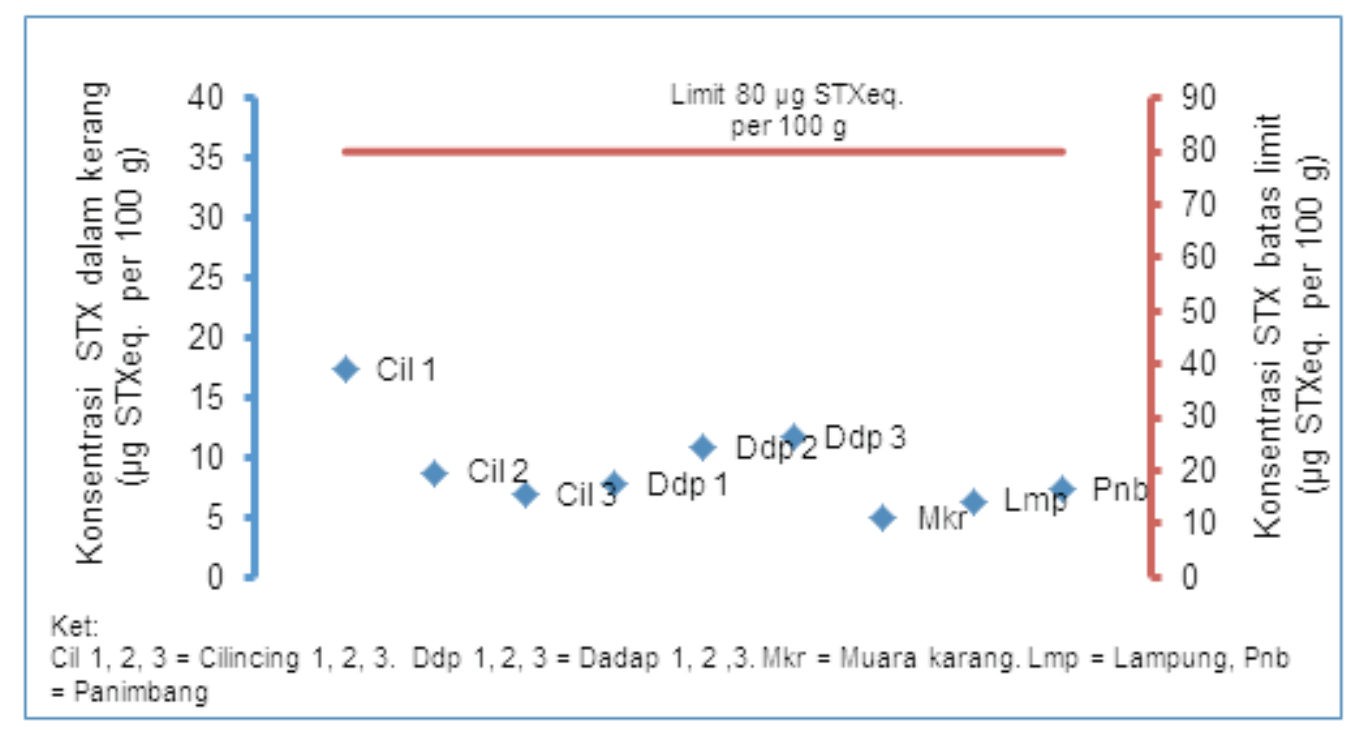

Gambar 3. Konsentrasi saksitoksin pada sampel kerang hijau dan baku mutu sebagai pembanding. Figure 3. Saxitoxin concentration of green mussel and the threshold limit as a comparator.

Banyak negara menetapkan $80 \mu \mathrm{g}$ STXeq. per 100 g sebagai batas konsentrasi yang diizinkan dalam daging kerang yang dipasarkan, walaupun ada negara yang menetapkan limit yang lebih rendah. Contohnya Filipina yang menetapkan besaran $40 \mu \mathrm{g}$ STXeq. per $100 \mathrm{~g}$ sebagai batas konsentrasi yang diizinkan. Tabel 1 memuat peraturan batas konsentrasi saksitoksin pada kekerangan di beberapa negara. Dalam SNI 460.1:2009 disebutkan bahwa syarat mutu keamanan pangan untuk kekerangan meliputi cemaran biologi (ALT, E. coli, Salmonella, Vibrio parahaemolyticus dan Staphylococcus aureus), cemaran kimia (kadmium, merkuri dan timbal) dan hayati (PSP, DSP dan ASP) (BSN, 2009).

Kebiasaan makan kerang dan konsentrasi saksitoksin dalam daging kerang akan memberikan jumlah pajanan (exposure) yang berbeda dari tiap tersebut hidup (Ashley, et al., 2005). Namun data kelimpahan alga pada waktu tersebut tidak tersedia, sehingga tidak bisa dicari korelasi antara konsentrasi saksitoksin dalam daging kerang dangan kelimpahan alganya.

Hasil penelitian Siregar (2002) menyatakan bahwa pada musim hujan, yang biasa terjadi pada bulan Desember, Januari dan Pebruari, kandungan organik di perairan Teluk Jakarta tinggi karena terbawa melalui sungai masuk ke perairan teluk. Memasuki musim peralihan dari hujan ke panas, yaitu Bulan April, biasanya kelimpahan fitoplankton menjadi lebih tinggi di bandingkan dengan musim hujan. Lebih tingginya kelimpahan fitoplankton disebabkan karena pada waktu-waktu tersebut, unsur hara di perairan tinggi dengan perairan yang lebih hangat, sehingga produktivitas fitoplankton pun meningkat. Selain itu, 
Tabel 1. Peraturan batas yang dizinkan untuk konsentrasi saksitoksin pada kekerangan di beberapa negara Table 1. Saxitoxin permitted limit regulation for mussel at various state

\begin{tabular}{clll}
\hline $\begin{array}{c}\text { Nol } \\
\text { Number }\end{array}$ & \multicolumn{1}{c}{$\begin{array}{c}\text { Negaral } \\
\text { State }\end{array}$} & \multicolumn{1}{c}{$\begin{array}{c}\text { Batas saksitoksin yang dizinkanl } \\
\text { Saxitoxin permitted limit }\end{array}$} & $\begin{array}{c}\text { Metoda Deteksil } \\
\text { Detection Method }\end{array}$ \\
\hline 1 & Uni Eropa & $80 \mu \mathrm{g}$ STXeq per $100 \mathrm{~g}$ & MBA \\
2 & Afrika (Moroko) & $80 \mu \mathrm{g}$ STXeq per $100 \mathrm{~g}$ & MBA \\
3 & Kanada & $80 \mu \mathrm{g}$ STXeq per $100 \mathrm{~g}$ & MBA \\
4 & Amerika Serikat & $80 \mu \mathrm{g}$ STXeq per $100 \mathrm{~g}$ & MBA \\
5 & Argentina & 400 MU per $100 \mathrm{~g}$ & MBA \\
6 & Chile & $80 \mu \mathrm{g}$ STXeq per $100 \mathrm{~g}$ & MBA \\
7 & Guatemala & $80 \mu \mathrm{g}$ STXeq per $100 \mathrm{~g}$ & MBA \\
8 & Mexico & $80 \mu \mathrm{g}$ STXeq per $100 \mathrm{~g}$ & MBA \\
9 & Panama & 400 MU per $100 \mathrm{~g}$ & MBA \\
10 & Uruguay & $400 \mathrm{MU}$ per100 g & MBA \\
11 & Venezuela & $80 \mu \mathrm{g}$ STXeq per $100 \mathrm{~g}$ & MBA \\
12 & China (Hongkong) & $400 \mathrm{MU}$ per $100 \mathrm{~g}$ & MBA \\
13 & Jepang & $400 \mathrm{MU}$ per100 $\mathrm{g}$ & MBA \\
14 & Plilipina & $40 \mu \mathrm{g}$ STXeq per $100 \mathrm{~g}$ & MBA, HPLC \\
15 & Singapura & $80 \mu \mathrm{g}$ STXeq per $100 \mathrm{~g}$ & MBA \\
16 & Korea & $400 \mathrm{MU}$ per $100 \mathrm{~g}$ & MBA, LC \\
17 & Australia & $80 \mu \mathrm{g}$ STXeq per $100 \mathrm{~g}$ & MBA \\
18 & New Zealand & $80 \mu \mathrm{g}$ STXeq per $100 \mathrm{~g}$ & MBA \\
19 & Indonesia & $80 \mu \mathrm{g}$ STXeq per $100 \mathrm{~g}$ & \\
\hline
\end{tabular}

Disarikan dari FAO 2004, kecuali Indonesia dari BSN, 2009/

Summary from FAO, 2004 except Indonesia from BSN 2009.

juga terjadi kenaikan persentase jumlah dinoflagelata, namun masih dalam komposisi kurang dari $10 \%$ (Siregar, 2002).

Sampel Cilincing 1 dan Dadap 1 yang mewakili musim kemarau mengandung saksitoksin yang hampir sama dengan sampel lainnya yang diambil pada musim hujan. Bahkan untuk sampel Cilincing, sampel yang diambil pada musim kemarau jauh lebih tinggi $(17,3 \mu \mathrm{g}$ STXeq. per $100 \mathrm{~g}$ dibandingkan dengan sampel pada musim hujan pada kisaran $6,9-8,8 \mu \mathrm{g}$ STXeq. per $100 \mathrm{~g}$ ). Dengan demikian, pengaruh musim tidak memberikan kecenderungan tertentu terhadap kandungan saksitoksin pada kerang hijau. Namun perlu penelitian lebih lanjut untuk melihat hubungan langsung antara konsentrasi alga jenis dinoflagelata dengan konsentrasi saksitoksin pada kerang hijau yang dilakukan pada waktu dan tempat yang sama.

Kejadian kematian massal ikan di Teluk Jakarta pada bulan Mei 2004 juga terjadi karena tingginya produktivitas primer perairan, yang pada saat kejadian, ditemukan 5 jenis dinoflagelata dengan kelimpahan $2,3 \times 10^{6}$ sel// (Thoha et al., 2007). Pada saat kejadian ledakan alga, diperkirakan konsentrasi saksitoksin pada kerang hijau bisa jauh lebih tinggi dibandingkan pada kondisi biasa. Dengan demikian, pencuplikan sampel dari pasar atau dari habitat tempat hidupnya harus secara rutin, baik pada saat ada kejadian ledakan alga atau tidak, sehingga dapat menjadi satu indikator aman atau tidaknya kerang hijau untuk dikonsumsi.

Sampel dari Teluk Lampung yang diperkirakan mempunyai konsentrasi STX lebih tinggi, karena tingginya kelimpahan alga $\mathrm{PbC}$ di Teluk Lampung (Widiarti, 2004), ternyata mengandung toksin yang tidak terlalu tinggi dan hampir sama dengan sampel dari Teluk Panimbang, Dadap 1 dan Cilincing 3 yaitu pada kisaran 6,3-7,7 $\mu \mathrm{g}$ STXeq. per $100 \mathrm{~g}$.

Lusiastuti (2003) meneliti kandungan saksitoksin dalam 100 sampel kerang (kerang bulu, kerang dara dan kerang hijau) yang diambil dari Tanjung Balai (Sumut), Bagan Siapi api (Riau), Mentol (Bangka belitung), Lampung dan Teluk Jakarta. Penentuan konsentrasi saksitoksin dilakukan dengan Elisa Reader dan didapatkan bahwa dari total 100 sampel, 6 di antaranya mengandung saksitoksin dengan 
rentang toksin mulai dari $24-70 \mu \mathrm{g}$ STXeq. per $100 \mathrm{~g}$. Dari ketiga jenis kerang, kerang bulu menempati urutan pertama, dikuti oleh kerang dara dan kerang hijau.

Penelitian yang pernah dilakukan oleh Mulyasari et al. (2003) menemukan konsentrasi saksitoksin sebesar 2,1-2,3 $\mu \mathrm{g}$ STXeq. per $100 \mathrm{~g}$ dalam sampel kerang hijau dan kerang dara asal perairan Tanjung Pasir Tangerang dan Cilincing pada tahun 2001, dengan uji MBA negatif, yaitu mencit yang digunakan untuk percobaan tidak mati.

Penentuan toksin PSP dalam kerang hijau pada sampel pasar juga secara rutin dilakukan oleh Dinas Kelautan dan Pertanian DKI Jakarta, namun hasil analisis menunjukkan not detected atau tidak terdeteksi (Komunikasi pribadi).

Penentuan konsentrasi saksitoksin dari 44 sampel yang terdiri dari gastropoda, clams, remis (mussel), tiram (oyster) dan kerang simping (scallops) yang diambil dari beberapa pasar di Shanghai dilaporkan oleh Wang \& Wu (2006). Hasil pengujian menggunakan metoda HPLC dan MBA, menunjukkan bahwa saksitoksin dalam sampel-sampel tersebut berkisar antara 42,0-78,5 $\mathrm{gg}$ STXeq. per $100 \mathrm{~g}$.

Penentuan konsentrasi saksitoksin pada kekerangan yang dikumpulkan dari pasar maupun dari habitat tempat hidupnya dimaksudkan untuk mengontrol peredaran toksin hayati dari kerang tersebut ke manusia melalui rantai makanan. Karena saksitoksin berdampak akut, yang memberikan reaksi langsung setelah mengkonsumsi kerang yang mengandung saksitoksin, maka mengetahui konsentrasi saksitoksin pada sampel terutama pada sampel pasar akan sangat membantu dalam menjamin keamanan pangan, khususnya produk kekerangan.

\section{KESIMPULAN}

Konsentrasi saksitoksin pada kerang hijau di Pasar Cilincing, Pasar Muara Karang dan Pasar Dadap serta Teluk Lampung dan Teluk Panimbang berkisar antara 4,928-17,3378 $\mu \mathrm{g}$ STXeq. per $100 \mathrm{~g}$ daging kerang dan masih di bawah ambang yang dipersyaratkan yaitu $80 \mu$ S STXeq. per 100 g. Konsentrasi saksitoksin pada kerang hijau ini dapat digunakan sebagai critical point dalam melindungi kesehatan masyarakat dari kerentanan jejaring makanan dan sebagai dasar informasi untuk kajian risiko toksin alga terutama saksitoksin dalam manajemen dan komunikasi risiko kepada masyarakat terutama untuk konsumen kerang.

\section{UCAPAN TERIMA KASIH}

Penelitian ini merupakan salah satu dari rangkaian penelitian untuk disertasi yang berjudul "Trasnformasi Saksitoksin dalam Jejaring Makanan (Foodwebs Transfer) dan Implikasinya Terhadap Kesehatan, Studi Kasus Transformasi Toksin Dinoflagelata dari Ledakan Alga di Teluk Jakarta)" dan terlaksana atas biaya dari Dana Riset DRPM Universitas Indonesia Tahun anggaran 2010 dalam bentuk Hibah Pascasarjana Universitas Indonesia dengan Nomor Kontrak 2665/ H2.R12/PPM.00.01. Bantuan standar saksitoksin dari Badan Tenaga Nuklir Nasional, c.q. Ibu Winarti dan kerjasama yang baik dengan BBP4B-KP yang mendukung dengan peralatan HPLC Detektor Fluoresensi dan bahan bahan pendukungnya.

\section{DAFTAR PUSTAKA}

AOAC Intl. 2006. AOAC Official Method 2005.06. Paralytic shellfish poisoning toxins in shellfish, prechromatographic oxidation and liquid chromatography with Fluorescence Detection, First Action 2005. J. AOAC Int. 88: 1714.

Ashley M. Y. L., Peter K. N. Y., Dennis P. H. H., Wang W. X., Rudofl S. S. W., and Paul K. S. M. 2005. Uptake and depuration of paralytic shellfish toxins in the greenlipped mussel, Perna viridis: a dynamic model. Environ. Toxycol. Chem. 24(1): 129-135.

Badan Standardisasi Nasional (BSN). 2009. Standar Nasional Indonesia, SNI 3460.1:2009. Tentang Daging Kerang Beku Bagian 1: Spesifikasi.

Cbwinfo. 2009. Saxitoxin Essential Data. http:// www.cbwinfo.com/Biological/Toxins/Saxitoxin.html. Diakses pada tanggal 5 Juni 2009.

Corrales, R.A. and Maclean, J.L. 2000. Receptor binding assay technique for harmful algal bloom toxins quantification: Reference manual UNDP/IAEA/RCA/ Subproject 2.4. application of nuclear techniques to address specific harmful algal bloom concerns. RRUPhilippine Nuclear Research Institute PNRI, Philippines.

Dam H., Colin S., Haley S., Avery D., Chen L., and Zhang H. 2009. Copepod resistance to toxic Pyhtoplankton. http://www.pices.int/publications/presentations/ Zoopl\%202007/ Zoop\%202007\%20S3/S3_Dam.pdf. Diakses pada tanggal 28 April 2010.

Dinas Peternakan, Perikanan dan Kelautan DKI Jakarta (Dinas Nakala). 2006. Kajian Eksistensi Budidaya Kerang Hijau di Teluk Jakarta. CV. Srikandi Utama Konsultan, Jakarta.

EFSA (European Food Safety Authority). 2009. Scientific Opinion of the Panel on Contamination in the Food Chain, Marine biotoxin in shellfish-Saxitoxin Group. http://www.efsa.europa.eu/EFSA/Scientific_Opinion / contam-op-ej1019-saxitoxin-marine-saxitoxin.pdf. Diakses pada tanggal 3 Desember 2009

FAO. 2004. Marine Toxin. Food and agriculture organization of the United Nations. http://www.fao.org/ docrep/. Diakses pada tanggal 11 April 2011. 
Hallegraeff, G. 1993. A review of harmful alga blooms and their apparent global increase. Phycologia. 32: 79-99.

Lusiastuti, A.M. 2003. Metode Deteksi Toksin Alga Laut dan Kejadiannya pada Kekerangan dan Ikan. Disertasi Sekolah Pascasarjana IPB. Bogor.

Mulyasari, Peranginangin, R., Suryaningrum, T.D. dan Sari, A. 2003. Penelitian mengenal keberadaan biotoksin pada biota dan lingkungan perairan Teluk Jakarta. Jurnal Penelitian Perikanan Indonesia. 9(5): 39-64.

Siregar, B.A. 2002. Studi kelimpahan, distribusi, dan struktur komunitas fitoplankton di perairan Teluk Jakarta. Skripsi Institut Pertanian Bogor (IPB). Bogor.

Sutomo. 1993. Kejadian red tide dan kematian massal udang jerbung dan udang windu dalam budidaya jaring apung di muara Sungai Kramat Kebo, Teluk Naga, Tangerang. Prosiding Simposium Perikanan Indonesia Satu, Bidang Sumber Daya Perikanan dan Penangkapan. Jakarta.

Thoha, H., Adnan, Q., Sidabutar, T., and Sugestiningsih. 2007. Note on the occurrence of phytoplankton and its relation with mass mortality in the Jakarta Bay, May and November 2004. Makara Sains. 11(2): 6367.

Wang, J. H. and Wu, J. Y. 2006. Marine algal toxins in shellfish from Shanghai markets and original sources following a large scale red tide occurrence. Bull. Environ. Contam. Toxicol. 77: 164-170

Widiarti, R. 2004. Keberadaan kista dari jenis mikroalga berbahaya di Teluk Lampung. http://cdc.eng.ui.ac.id/ article/articleprint/1505/-1/25/. Diakses pada 23 Januari 2009. 
